\title{
Avoiding taxes: banks' use of internal debt
}

\author{
Franz Reiter ${ }^{1} \cdot$ Dominika Langenmayr $^{2}$ (D) Svea Holtmann ${ }^{3}$
}

Published online: 25 September 2020

(c) The Author(s) 2020, corrected publication 2020

\begin{abstract}
This paper investigates how multinational banks use internal debt to shift profits to lowtaxed affiliates. Using regulatory data on multinational banks headquartered in Germany, we show that banks use this tax avoidance channel more aggressively than non-financial multinationals do. We find that a ten percentage points higher corporate tax rate increases the internal net debt ratio by 5.7 percentage points, corresponding to a $20 \%$ increase at the mean. Our study also takes into account the existence of conduit entities, which simply pass through financial flows. If conduit entities are systematically located in low-tax countries, previous studies may have underestimated the extent of debt shifting.
\end{abstract}

Keywords Profit shifting $\cdot$ Internal debt $\cdot$ Multinational banks $\cdot$ Taxation

JEL Classification H25 · G21 · F23

\section{Introduction}

In the last years, the Organisation for Economic Co-operation and Development (OECD) and G20 have started an unprecedented initiative against Base Erosion and Profit Shifting (BEPS). This initiative builds on a large body of empirical research that has identified the main channels of BEPS (Dharmapala 2014). One of these channels is the strategic use of debt, exploiting the tax-deductibility of interest payments. Most of this empirical literature, however, excludes the financial sector. This

Dominika Langenmayr

dominika.langenmayr@ku.de

Franz Reiter

franz.reiter@mail.de

Svea Holtmann

sholtmann@ku.de

1 University of Munich, Akademiestr. 1/II, 80799 Munich, Germany

2 KU Eichstätt-Ingolstadt and CESifo, Auf der Schanz 49, 85049 Ingolstadt, Germany

3 KU Eichstätt-Ingolstadt, Auf der Schanz 49, 85049 Ingolstadt, Germany 
omission is all the more surprising as, in many countries, the financial sector contributes around a quarter of corporate tax revenues. ${ }^{1}$ The OECD has recognized this gap and published a discussion draft entitled "Approaches to Address BEPS Involving Interest in the Banking and Insurance Sectors" as part of Action 4 on the limitation of interest deductions in $2016 .^{2}$

The tax deductibility of interest payments enables both base erosion and profit shifting: When a bank borrows from a third party, the resulting interest payments lower its taxable profit. Higher risks for shareholders and regulatory requirements limit the extent to which banks can erode their tax base in this way. When a bank affiliate borrows internally, i.e. from a different subsidiary of the same bank group, profit is shifted to that subsidiary. The interest payment is tax deductible in the borrowing affiliate, while the interest income is taxed in the lending affiliate-usually located in a strategically chosen low-tax country. As internal debt does not increase the overall leverage of the bank group, it does not entail risks for the ultimate shareholders. Previous literature (de Mooij and Keen 2016; Heckemeyer and de Mooij 2017) has studied the tax responsiveness of external debt, i.e. base erosion. However, to our knowledge, no previous paper studies how banks can use (internal) interest payments to shift profits to low-tax jurisdictions.

Our paper aims to fill this gap. Using administrative data provided by the German central bank, we show that banks indeed use internal debt to shift profits to lowtax countries, and that they do so more aggressively than non-financial firms. Our dataset, the External Positions of Banks database, has information on bilateral financial flows between the foreign subsidiaries and branches of all German multinational banks. Using panel regressions with and without affiliate fixed effects, we find that a ten percentage points higher corporate tax rate increases the internal debt-to-assets ratio by about 5.1 percentage points. This absolute response is much stronger than the effect that Fuest et al. (2011) and Buettner et al. (2012) find for non-banks in a comparable setting. ${ }^{3}$ Thus, the banking sector uses internal debt shifting more aggressively than other sectors of the economy.

A second contribution of this paper is methodological. It arises from the importance of conduit entities in internal debt financing. Such conduit affiliates pass through internal loans, without shifting any profits away from themselves. There are three potential reasons why multinationals might use conduit entities: First, the conduit entities might simply serve as financial hubs, coordinating internal financing.

\footnotetext{
1 The financial sector in Germany in 2014 paid $26 \%$ of total corporate tax revenues (Statistisches Bundesamt 2019). Finance and insurance firms in the U.S. in 2015 contributed $31 \%$ of total pre-tax profits (Internal Revenue Service 2019).

${ }^{2}$ See https://www.oecd.org/tax/aggressive/discussion-draft-beps-action-4-banking-and-insurance-secto r.pdf.

3 Fuest et al. (2011) and Buettner et al. (2012) show that a ten percentage points higher corporate tax rate increases internal debt-to-asset ratios in non-banks by 1.77-2.14 percentage points. When relating these figures to the sample mean of internal debt-to-asset ratios ( $42 \%$ in our sample, $23 \%$ and $28 \%$ in these previous studies on German non-banks), our results correspond to an increase by about $12 \%$, compared to $7 \%$ to $8 \%$ for non-banks. Note that due to different data sources, the definition of the internal debt-to-asset ratio is not fully comparable.
} 
Second, passing loans through an additional affiliate also impedes the uncovering of the tax avoidance scheme by the tax authorities or the media. Third, the passthrough loans offer an additional profit shifting possibility by mispricing the related interest rates. Despite the existence of these pass-through loans, the literature on internal debt shifting uses internal gross liabilities as proxy for the volume of internal debt shifting. If the location of the conduit entities correlates with tax rates, this proxy systematically underestimates the true amount of debt shifting.

We show that conduit entities are indeed systematically located in low-tax countries. To account for the arising bias, we propose a new dependent variable, the internal net-debt-to-assets ratio. Briefly put, it captures internal liabilities net of internal claims relative to total assets. Using this variable, we estimate a slightly higher tax rate coefficient, even though the sample mean of the internal net-debt-toassets ratio is substantially lower. We find that a ten percentage points higher corporate tax rate increases the internal net-debt-to-assets ratio by 5.7 percentage points, which corresponds to an increase of $20 \%$ at the mean.

Our results also add to the current policy debate on multinational taxation. A main policy-relevant finding is that profit shifting in the financial sector is substantial: The size of the financial sector in the economy, combined with the high tax elasticities found in this paper, implies a substantial potential revenue loss. At the same time, the main current anti-tax avoidance rules, controlled-foreigncorporation (CFC) and thin capitalization rules, either do not apply to or are not effective in the financial sector. CFC rules stipulate that passive income from a low-tax subsidiary is added to the profit of the parent company and taxed there. Usually, interest payments on internal debt are passive income, but many countries have exemptions for banks, as interest income is their main business. ${ }^{4}$ When interest income is deemed active income, CFC rules are toothless for banks. Moreover, CFC rules are not compatible with EU law and are currently not applied within the EU. Thin capitalization rules usually limit the deductibility of net interest expenses to a certain fraction (often 30\%) of an adjusted earnings measure. Several countries exempt banks from these rules (e.g. Belgium, France, Greece, Italy, Spain) or have more lax rules for banks (e.g. China, Japan, United Kingdom). In other countries (e.g. Germany, Portugal, USA), thin capitalization rules apply to banks; however, as these rules consider net interest (i.e. interest expense minus interest income), they are usually not relevant for banks due to the high levels of interest income. Summing up, the existing anti-avoidance rules tackling debt shifting are not effective for banks even though they also use this tax avoidance channel. Therefore, there is a need for specific anti-tax avoidance rules in the financial sector. Such rules could, for example, limit the deductibility of internal interest payments.

This paper contributes to three different strands of literature. First, it adds to a large literature on profit shifting (recently surveyed by Beer et al. 2020). Within this literature, several papers focus on the use of internal debt, e.g. Fuest et al. (2011), Buettner et al. (2012), Buettner and Wamser (2013), Blouin et al. (2014), Egger et al. (2014) and

\footnotetext{
${ }^{4}$ We discuss the German CFC rule and whether its exemption for banks applies in more detail in Sect. 2.1.
} 
Overesch and Wamser (2014). Similarly to our paper, Overesch and Wamser (2014) also use bilateral internal debt data; they also find significantly positive effects of the bilateral tax rate differential, the most precise measure for debt shifting incentives. We contribute to this literature in two ways: As a first contribution, we point out the importance of modelling conduit entities, showing that the dependent variable should be net (and not gross) internal debt. As a second contribution, we focus on banks, an industry where debt financing plays a particularly large role.

Second, we contribute to the emerging literature focusing on profit shifting in the banking sector. Merz and Overesch (2016) show in a worldwide sample of bank affiliates that corporate tax rates are negatively associated with reported pre-tax profits, indicating that banks indeed engage in profit shifting. While they cannot identify precise profit shifting channels in their data, they find some suggestive evidence that internal debt shifting might play a role. Langenmayr and Reiter (2017) identify another potential channel by showing that banks shift profits through the relocation of proprietary trading assets to lower-taxed affiliates.

Lastly, we contribute to the literature studying how taxes affect capital structure choices in the financial sector. While there is plenty of evidence on how taxes affect the capital structures of non-financial firms (see, for example, the meta-analysis of Feld et al. 2013), only a few papers look at the financial sector, despite the importance of bank leverage as a risk factor for financial crises. de Mooij and Keen (2016) first show analytically that higher tax rates should increase both conventional debt as well as hybrid financing in the banking sector, a result reflecting the tax deductibility of interest payments. They confirm this relationship empirically for conventional debt, but not for hybrid financial instruments. Heckemeyer and de Mooij (2017) compare the responsiveness of debt finance to taxation for banks and non-banks. They find that while small banks are more responsive to taxation than non-banks of similar size, large banks are less responsive compared to both smaller banks and similarly sized non-banks. $\mathrm{Gu}$ et al. (2015) regress overall debt-to-assets ratios on the difference between the tax rate an affiliate faces and the group's average tax rate. As they cannot distinguish between internal and external debt they also cannot separate this effect into internal debt shifting and the classical debt financing incentive. In contrast, our focus is on the tax responsiveness of internal debt, which we observe directly and at a bilateral level in the Bundesbank data. The presumed underlying motive is to shift profits from a high-tax to a low-tax location without increasing the indebtedness of the bank group as whole. We will discuss below how this decision interacts with the conventional tax shield motive to take on additional (external) debt in response to higher tax rates.

The next section discusses relevant institutional issues and the role of conduit entities. Section 3 presents the empirical specification that we use for identification. Section 4 describes the data and provides descriptive evidence, and Sect. 5 presents regression results. Section 6 concludes. 


\section{Debt shifting in the banking sector}

\subsection{Institutional background}

Financing in the banking sector relies heavily on debt: Banks usually have little equity relative to debt. The Bank for International Settlements reports an equityto-total-assets ratio of only 6.9\% for banks worldwide in 2015 (Bank for International Settlements 2017). German banks, constituting the sample in this paper, had on average an equity-to-total-assets ratio of $7.0 \%$ in 2015 , compared to $28.2 \%$ in the non-financial sector (Deutsche Bundesbank 2016). Berg and Gider (2017) find that different asset risks can largely explain this capitalization gap between banks and non-banks. The main outside determinants of banks' capital structure are taxation and regulation, which we will now address in turn.

First, consider taxation. In almost all countries, interest payments on debt are tax deductible while dividend payments are not. Thus, the tax system encourages the use of debt over equity to finance operations - the debt tax shield or debt bias. Thus, third-party debt lowers taxable profits (i.e. the tax base) and therefore implies a lower tax burden. Multinational firms, however, have an additional way to use debt to lower their tax payments: They can use intra-company lending to shift interest payments from affiliates in high-tax countries to affiliates in low-tax countries-debt shifting. Internal debt keeps the profits of the bank group as a whole constant, but lowers the tax burden by shifting profits to a low-tax country. ${ }^{5}$

Therefore, the tax consequences of external and internal debt are quite different: The first lowers the total tax base, while the second shifts profits from high- to low-tax countries. But do the decisions to take on external and internal debt influence each other? Møen et al. (2019) model theoretically the optimal choice of internal and external debt in a multinational firm. While they base their analysis on a generic model of a multinational firm and do not analyse banks, the main motives should be identical in the financial sector. A fundamental insight from their analysis is that the choice of internal and external debt is independent of each other if each has different costs for the firm. These costs are indeed very different: External debt has well-known costs, such as the use of debt as a disciplining device for overspending managers, and the need to balance indebtedness against the probability of costly bankruptcy. Internal debt neither affects the risk of bankruptcy, nor disciplines managers, nor does failure to repay trigger outside enforcement. The costs of internal debt arise, e.g. from compliance costs with tax rules, such as thin capitalization rules and/or controlled-foreign-company

\footnotetext{
5 The negative inter-bank market rates that arose for certain funds in 2015 could reverse the debt shifting incentives as internal loans have to be priced according to the arm's length principle. Nevertheless, we do not expect that negative interest rates have substantially affected debt shifting behaviour of multinational banks so far: Banks have some discretionary powers for overpricing internal loans and they might also choose longer time periods to justify higher interest rates. The sample period in our regressions is from June 2010 to December 2015. As a robustness check we also estimated our regressions excluding all observations in 2015 from the sample and arrived at very similar results.
} 
(CFC) rules. ${ }^{6}$ Therefore, we treat the decisions to take on internal and external debt as separate and focus exclusively on internal debt in this paper. ${ }^{7}$

We start by discussing the tax rules that may limit debt shifting. Many countries have implemented thin-capitalization rules or earnings stripping rules. These rules restrict the tax deductibility of interest payments to a certain amount or to a defined debt-to-equity ratio. Interest payments exceeding these thresholds do not reduce the tax base and therefore make debt shifting less attractive. ${ }^{8}$ However, most countries either exclude banks from the scope of these rules (e.g. Spain and Italy) or apply more generous thresholds that effectively exclude banks from the scope (e.g. Japan and UK). Germany applies its thin-capitalization rule also to financial corporations. However, the restriction of interest deductibility only applies on net interest expenses, i.e. total interest expenses net of total interest income. Since interest income is a main source of income for financial corporations, the focus on net interest expenses effectively also excludes banks from the scope of the thin capitalization rule. Debt shifting may further be less attractive for tax avoidance if the source country levies a withholding tax on interest payments. Among affiliates in European countries, there are no withholding taxes on interest payments due to the Interest and Royalties Directive (Council Directive 2003/49/EC of 3 June 2003). Additionally, most double tax treaties reduce or eliminate the withholding tax on interest payments.

In addition, several countries have controlled-foreign-corporation (CFC) rules that add passive income (e.g. interest income) in low-taxed affiliates to the tax base of the parent company (see e.g. Ruf and Weichenrieder 2012), allowing for a tax credit for the taxes already paid abroad. If binding, these rules would prevent debt shifting. However, some countries such as, e.g. Japan, the United Kingdom and the United States completely or in large part exclude income from banking from being affected by CFC rules. According to the prevailing view, ${ }^{9}$ also Germany completely excludes income from banking under the relatively loose condition of having a 'commercially organized business operation' in the low-tax country. ${ }^{10}$ This exclusion of banks from CFC legislation in some major countries provides additional scope for debt shifting compared to multinationals in other sectors.

Second, let us consider banking regulation. Since a large part of bank regulations addresses the capital structure of a bank, debt shifting may be more difficult for banks than for non-financial firms. Merz and Overesch (2016) find evidence

\footnotetext{
${ }^{6}$ E.g. Mintz and Smart (2004) and Fuest and Hemmelgarn (2005) also model the costs of internal debt as separable.

${ }^{7}$ Of course, an affiliate of a multinational firm may also take on internal debt to profit from the classical debt tax shield. The fact that the associated interest payments arrive in another affiliate of the same multinational instead of third-party debt holders would then be a side effect and not the rationale behind the internal debt. Desai et al. (2004) indeed show that in countries with underdeveloped capital markets or weak creditor rights, internal debt is a substitute for external debt. This motive, however, should not play a role in regressions with bilateral data, where we show that the precise tax rate differential between two countries affects internal lending between affiliates in these countries.

${ }^{8}$ See e.g. Buettner et al. (2012) and Blouin et al. (2014) for empirical evidence.

${ }^{9}$ See Blümich and Vogt (2019) Rz. 28. The term prevailing view refers to the most widely held opinion in a legal discourse.

10 The German Federal Fiscal Court decided in 2010 that it is not even necessary that the foreign affiliate has employees or offices to fulfil the condition of a 'commercially organized business operation' (BFH 13 Oct 2010, I R 61/09); having a service contract with another affiliate is already sufficient.
} 
suggesting that capital regulations affect profit shifting activities. In most countries, the capital requirements base on Basel III, which implemented a mandatory minimum equity-to-total-assets ratio of 3\% in 2018 (with variable mark-ups for globally systemically relevant banks). ${ }^{11}$ At the level of the parent company, the equity-tototal-assets ratio is calculated on a consolidated basis. Thus, as this ratio contains both the equity and the total assets of all consolidated group members, it does not constrain internal debt shifting (as long as the consolidated equity-to-total-assets ratio fulfils the minimum requirement). ${ }^{12}$ However, foreign subsidiaries additionally have to fulfil the capital requirements in their home country. In contrast, foreign branches are only regulated on a consolidated basis in the home country of the parent company. These rules also apply to Germany, the home country of all multinational banks in our sample. ${ }^{13}$

Another potential issue at the border of regulation and taxation that might affect debt shifting in the banking sector is the implementation of bank levies in several countries in the aftermath of the financial crisis. In most countries, internal liabilities are also subject to the levy, increasing the costs of debt shifting. Germany introduced a bank levy in 2011 with progressive tax rates. However, the German levy includes a size threshold of 300 million euros, exempting $77 \%$ of German banks (Buch et al. 2016). Given this exemption of the majority of banks and the relatively low bank levy rates (also in other countries, see Devereux et al. 2019, for an overview), especially compared to the potential tax savings from internal debt, the German levy does not seem to affect debt shifting substantially. Furthermore, since the adoption of European bank levy standards in 2015 bank levy rates on intragroup liabilities are reduced by half.

\subsection{The role of conduit entities}

A threat to the empirical identification of internal debt shifting are conduit entities that simply pass through liabilities, by taking up a loan from a related affiliate and passing it on to another affiliate. In these conduit affiliates interest income from conduit claims offsets interest expenses due to conduit liabilities. Thus, using internal gross liabilities as proxy for profits shifted out through internal debt leads to biased estimates. Nevertheless, previous empirical studies on debt shifting have not considered the existence of conduit entities and their potential impact on the estimation of debt shifting.

\footnotetext{
11 For a discussion of the Basel III compulsory minimum equity-to-total-assets ratio requirement see Dermine (2015).

12 If a banking group also contains non-financial but commercial entities, these investments reduce the banks' capital when calculating the required ratios if certain materiality thresholds are fulfilled, see Bas (2006).

13 In Germany, financial institutions are supervised by the Federal Financial Supervisory Authority (BaFin) and the Bundesbank. The German Banking Act (Kreditwesengesetz, KWG) complemented by European law [especially Directive 2013/36/EU on Capital Requirements (Capital Requirements Directive CRD IV) and Regulation (EU) 575/2013 on prudential requirements for credit institutions and investment firms (Capital Requirements Regulation)] determine the core regulations applicable to German banks. In line with Basel III, these German regulations require a minimum consolidated equity-tototal-assets ratio of $3 \%$ and do not target internal debt shifting.
} 
This paper accounts for conduit entities in internal debt financing. We define conduit affiliates as entities that simply pass-through debt from one related affiliate to another affiliate. Figure 1 illustrates the simplest example of such an internal conduit debt scheme: The tax haven affiliate faces a corporate tax rate equal to $t_{\mathrm{Ha}}$ and lends $K_{C}$ units of money to the conduit affiliate which is taxed by $t_{C}>t_{H a}$. Through the related interest payments profits are shifted from the conduit affiliate to the tax haven affiliate. Moreover, also the headquarter wants to borrow $K_{H Q}$ from the tax haven affiliate. Instead of directly taking out a loan from the haven affiliate, it can channel this loan via the conduit affiliate. In the headquarter the interest payments for $K_{H Q}$ are tax-deductible. In the conduit entity the pass-through is completely tax-neutral (assuming that the loans are subject to the same interest rates) as interest expenses to the haven affiliate offset the interest income from the headquarter. In the tax haven affiliate interest income is taxed at rate $t_{\mathrm{Ha}}<t_{\mathrm{HQ}}$. Hence, from a tax perspective, taking out the loan through the conduit entity is equivalent to direct lending.

While passing the loan through the conduit entity is neutral regarding the tax treatment, it may be preferable for several reasons. First, additional debt streams offer additional scope for mispricing of internal loans. This form of transfer pricing is a profit shifting channel different from internal debt shifting and is not the subject of this paper. Second, passing internal debt through conduit subsidiaries can simply reflect real structures: the conduit entity can serve as a financial hub that plays the role of a capital coordinator for the group and distributes capital from tax havens to affiliates. This also allows to re-bundle debt, for instance by taking out loans from several low-taxed subsidiaries and distributing them to several high-taxed affiliates through the hub. Third, multinationals might also use conduit entities to conceal the real origin of internal loans. As tax avoidance schemes of several multinationals were recently addressed in the media, multinationals might be interested in making these schemes increasingly opaque, although they are legal. Additionally, tax administrations may focus on loans directly from tax havens, and are less likely to check in detail loans from a conduit country, as the pass-through nature of these loans is hidden from them. Thus, the use of conduits may lower the probability of detailed checks by the tax administration.

How does the use of conduit subsidiaries affect the estimation of internal debt responses to tax rates? In the simple example in Fig. 1, passing $K_{H Q}$ through the conduit affiliate increases the internal debt levels of both the conduit affiliate and the headquarter. However, $K_{H Q}$ does not shift any profit out of the conduit affiliate. This double-counting of internal debt effectively assigns artificially high internal debt levels to these conduit entities. If the location of the conduit is correlated with tax rates, this leads to a bias in classical debt shifting regressions employed in earlier literature (which uses internal liabilities as the dependent variable). In Sect. 3.2 we elaborate on the sign of this bias.

Apart from internal debt shifting, some studies consider the use of conduit entities by multinationals in different contexts. Mintz (2004) models that multinationals give equity to a low-taxed conduit entity which then passes the capital as a loan to another higher-taxed affiliate. While the first transaction in most countries is not related with profit shifting (as dividends are usually largely tax-exempt), the loan shifts profits from the high-taxed affiliate to the lower-taxed conduit entity. 
Johannesen (2014) models how conduit entities can be used for cross-border hybrid instruments intended to avoid taxes. Mintz and Weichenrieder (2010) empirically investigate factors determining why multinationals might use intermediate entities for investing in their subsidiaries. In the same direction, Garcia-Bernardo et al. (2017) identify five countries that are most important for passing-through investments. Dyreng et al. (2015) find that U.S. multinationals systematically supply equity to their subsidiaries through conduit entities located in countries with low taxes on equity distributions. Literature on internal debt shifting so far has not considered the use of conduit entities.

In addition to these tax-related reasons for using conduit entities, banks also use conduit entities for non-tax reasons. First, multinational banks use such financial networks to manage liquidity. Cocco et al. (2009), e.g. find that banks with a larger imbalance in their reserve deposits tend to borrow funds from related banks and pay a lower interest rate on these funds than they would pay on funds from non-related banks. Second, multinational banks use their financial network to allocate systemic risk within the bank. Elliott et al. (2014), e.g. find that a more diversified financial network provides a better insurance against the failure of one specific bank in the network.

\section{Empirical specification}

This section develops the baseline empirical specification to estimate internal debt shifting, first with the classical dependent variable used in previous literature and afterwards with the new variable that accounts for conduit debt. In Sect. 3.3 we then adapt the empirical specification to bilateral internal debt data.

\subsection{Baseline model}

Analogously to earlier literature on internal debt shifting in non-financial sectors, we first estimate the effect of corporate tax rates on internal debt-to-asset ratios, using variation in tax rates within a multinational bank group across countries and across time. Accordingly, the baseline regression equation is

$$
\frac{\text { InternalLiabilities }_{i k t}}{T A_{i k t}}=\beta_{0}+\beta_{1} C T R_{i k t}+\beta_{2} X_{i k t}+\gamma_{t}+\delta_{k}+u_{i k t},
$$

where InternalLiabilities $s_{i k t}$ are internal liabilities in affiliate $i$ of bank group $k$ in period $t$. We assume that these internal liabilities refer to plain vanilla debt which classifies as debt for tax purposes in all involved countries. ${ }^{14} T A_{i k t}$ are total assets. $C T R_{i k t}$ is the statutory corporate income tax rate affecting affiliate $i$ and $X_{i k t}$ is a

\footnotetext{
14 If internal liabilities contained hybrid financial instruments to some extent, affiliate $i$ could still deduct the resulting interest payments for tax purposes. Additionally, the parent company would receive tax exempt dividend income. In this case, we would overestimate the effect on internal lending in favour of tax avoidance with hybrid financial instruments.
} 


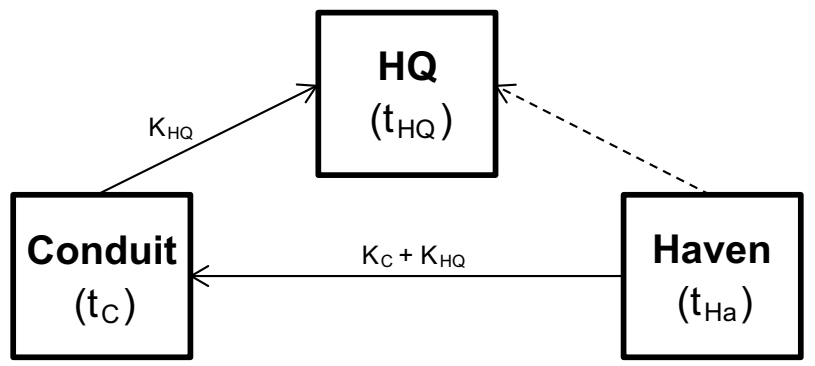

Fig. 1 Conduit affiliate in internal debt financing

vector of control variables described below. $\gamma_{t}$ are time fixed effects, $\delta_{k}$ are bank group fixed effects and $u_{i k t}$ is the error term. If multinational banks indeed shift profits via internal debt, we expect a positive estimate for $\beta_{1}$.

To capture the size of an affiliate, we include the natural logarithm of total assets as a bank-specific control variable into $X_{i k t}{ }^{15}$ Earlier literature uses further subsidiary-level controls such as collateral, tangibility, payroll expenses, and off-balance sheet items to decrease the variance. ${ }^{16}$ We are unable to do so as our dataset does not include this information. As these subsidiary-level control variables are supposed to proxy for the capacity to take on external debt and to give collateral, they are clearly relevant for analysing the overall debt-to-asset ratio of a bank. However, their influence on internal debt is less clear. We thus find omitted variable bias unlikely to arise from the omission of these variables.

As the magnitude of a bank group's engagement in a country and thereby also the use of internal debt might be influenced by the macroeconomic situation, we further control for GDP growth, consumer price inflation rates and the natural logarithm of the host country's nominal GDP. A further control is a country's share of the financial sector in its gross value added, which should account for countries that act as important financial centres.

Moreover, we include two regulatory variables that potentially influence a bank group's activities and financing decisions in a country: First we incorporate the minimum regulatory capital requirement for banks and second we control for the capital regulatory index that is provided by Barth et al. (2013) based on the World Bank (2011) survey on bank regulation. This index captures whether a country's capital requirement is adjusted for individual risks of banks, whether the regulatory capital is adjusted for certain market value losses, and whether certain funds may be used to capitalize a bank. It ranges from 0 to 10 , with higher values indicating greater stringency of capital regulation. These variables also indirectly control for financial networks that are set up in response to regulatory requirements.

\footnotetext{
15 In additional tests, we control for the growth rate of a subsidiary measured by the annual change in total assets (following Merz and Overesch 2016). Adding this control variable does not change our results.

16 See e.g. Merz and Overesch (2016) and Heckemeyer and de Mooij (2017).
} 
Another issue with the sample in this paper is that all bank groups are headquartered in Germany. As profit shifting is found to be less intense out of headquarters (see Dischinger et al. 2014), as a robustness check we also exclude all German headquarters from the sample and re-estimate the regressions. The results we find are very similar.

\subsection{Accounting for conduit entities}

As outlined in Sect. 2.2, the simple internal-liabilities-to-total-assets ratio also includes conduit liabilities that are only passed through and hence do not reflect actual profit shifting. To solely capture internal debt that effectively shifts profits out of the respective affiliate, we have to subtract such pass-through loans: The ratio of internal debt net of pass-through loans divided by $i$ 's total assets is the appropriate measure for debt shifting out of affiliate $i$. A straightforward debt shifting regression with this ratio as dependent variable is

$$
\frac{\text { InternalDebt }_{i k t}^{*}}{T A_{i k t}}=\beta_{0}+\beta_{1} C T R_{i k t}+\beta_{2} X_{i k t}+\gamma_{t}+\delta_{k}+u_{i k t} .
$$

Here InternalDebt $t_{i k t}^{*}$ denotes internal debt net of pass-through loans, and the other variables are as defined above. Previous internal debt shifting regressions, as in regression equation (1), do not subtract pass-through loans in the dependent variable: The common dependent variable is $\frac{\text { InternalLiabilities }_{i k t}}{T A_{i k t}}=\frac{\text { InternalDebt }_{i k t}^{*}+e_{i k t}}{T A_{i k t}}$, where $e_{i k t}$ is debt that is passed through to other affiliates. The regressions therefore estimate

$$
\frac{\text { InternalLiabilities }_{i k t}}{T A_{i k t}}=\beta_{0}+\beta_{1} C T R_{i k t}+\beta_{2} X_{i k t}+\gamma_{t}+\delta_{k}+u_{i k t}+\frac{e_{i k t}}{T A_{i k t}} .
$$

If the choice of the conduit affiliate's location is correlated with the corporate tax rate, there is a bias in the estimate for $\beta_{1}$ similar to the bias that arises with a systematic measurement error in the dependent variable. As pass-through debt always increases the amount of internal gross liabilities, the correlation between the dependent variable in Eq. (3) and $\frac{e_{i k t}}{T A_{i k t}}$ is positive by definition. Therefore, the sign of the bias is equal to the sign of the covariance between $\frac{e_{i k t}}{T A_{i k t}}$ (the 'left-out variable' here) and $C T R_{i k t}$ :

$$
\operatorname{Cov}\left(C T R_{i t}, \frac{e_{i t}}{T A_{i t}}\right)=\frac{1}{T} \frac{1}{N} \sum_{t=1}^{T} \sum_{i=1}^{N}\left(C T R_{i t} * \frac{e_{i t}}{T A_{i t}}\right)-\overline{C T R} * \frac{1}{T} \frac{1}{N} \sum_{t=1}^{T} \sum_{i=1}^{N}\left(\frac{e_{i t}}{T A_{i t}}\right),
$$

where $N$ is the number of affiliates, $T$ is the number of sample periods and $\overline{C T R}$ is the sample mean of $C T R_{i t}$. For the sake of brevity we drop the bank group indicator $k$ from here on, as it is fully included in the bank indicator $i$. In all subsidiaries that do not serve as conduit entities $e_{i t}$ is equal to zero. Therefore, one can rewrite (4): 


$$
\operatorname{Cov}\left(C T R_{i t}, \frac{e_{i t}}{T A_{i t}}\right)=\frac{1}{T} \frac{1}{N} \sum_{t=1}^{T} \sum_{i=1}^{H}\left(C T R_{i t} * \frac{e_{i t}}{T A_{i t}}\right)-\overline{C T R} * \frac{1}{T} \frac{1}{N} \sum_{t=1}^{T} \sum_{i=1}^{H}\left(\frac{e_{i t}}{T A_{i t}}\right),
$$

where subsidiaries $i=1, \ldots, H$ (with $H \leq N$ ) serve as conduit affiliates. Rearranging gives

$$
\left.\operatorname{Cov}\left(C T R_{i t}, \frac{e_{i t}}{T A_{i t}}\right)=\frac{1}{T} \frac{1}{N} \sum_{t=1}^{T} \sum_{i=1}^{H}\left[\left(C T R_{i t}-\overline{C T R}\right) * \frac{e_{i t}}{T A_{i t}}\right)\right] .
$$

Equation (6) is negative if the weighted average tax rate of conduit affiliates is lower than the average tax rate of all affiliates in the sample, with weights being equal to the pass-through-debt-to-total-assets ratio $\frac{e_{i t}}{T A_{i t}}$. Hence, if conduit entities systematically face lower tax rates than the average of affiliates, classical debt shifting regressions estimate a downward biased coefficient for the corporate tax rate. If conduit entities are, vice versa, located in higher-taxed affiliates, there is an upward bias in estimates for $\beta_{1}$ in Eq. (3). As Sect. 4.2 shows, banks in our sample locate their conduit entities systematically in low-tax countries, resulting in a downward biased estimate for $\beta_{1}$ when using the classical dependent variable.

To account for the use of conduit affiliates in internal debt financing, we additionally use internal net debt (relative to total assets) as the dependent variable. This variable is defined as

$$
\text { IntNetDebt }_{i k t}=\max \left(\text { InternalLiabilities }_{i k t}-\text { InternalClaims }_{i k t} ; 0\right),
$$

where InternalLiabilities $s_{i k t}$ denotes affiliate $i$ 's internal liabilities and InternalClaims $s_{i k t}$ are claims to related parties of bank group $k$ in period $t$. Therefore, the difference is the effective amount of internal debt that shifts profits out of affiliate $i$, accounting for the potential existence of conduit debt. If internal claims of an affiliate are larger than its internal liabilities, effectively no profits are shifted out via the internal debt channel and IntNetDebt ${ }_{i k t}$ is zero. The empirical specification for estimation with the ratio of IntNetDebt ${ }_{i k t}$ to total assets as the dependent variable is equivalent to Eq. (1):

$$
\frac{\text { IntNetDebt }_{i k t}}{T A_{i k t}}=\beta_{0}+\beta_{1} C T R_{i k t}+\beta_{2} X_{i k t}+\gamma_{t}+\delta_{k}+u_{i k t} .
$$

The explanatory variables are as defined in Sect. 3.1. With internal debt shifting we expect a positive estimate for $\beta_{1}$ in Eq. (8). As argued above, the estimated tax rate coefficient is expected to be higher with internal net debt as the dependent variable compared to internal liabilities if the conduit entities are located in low-tax countries, and to be lower if conduit affiliates are located in high-tax countries. As a robustness check we again re-estimate equation (8) with exclusion of German headquarters to account for the sample's idiosyncrasy that all bank groups are headquartered in Germany.

Another issue is that country characteristics other than the corporate tax rate influence a bank affiliate's volume of internal net debt. To account for this, we 
conduct a robustness check by additionally including bank affiliate fixed effects into regression equation (8). We then only exploit corporate tax rate changes in the sample period to identify the tax effect on internal debt, measuring basically how banks adjust the volume of effectively profit-shifting debt in response to changes in the corporate tax rate.

As stated in Sect. 2.2, there are other, non-tax reasons for intrafirm lending within a multinational bank. Since we do not have data on liquidity or risk allocation, we cannot control for these factors in our model. The change in tax rates should, however, not affect the attractiveness of a conduit entity in these other dimensions. Therefore, insofar as these factors are constant over time (or changes are not correlated with tax rate changes), in the specifications with affiliate fixed-effects, we effectively control for such non-tax related determinants of internal debt.

Lastly, note that while our focus in this paper is on internal debt, similar problems may occur when studying total debt. Consider, for example, a case where a conduit entity takes on external debt and passes it on internally to the affiliate. In this case, we observe increasing external (or total) debt (and internal claims) at the level of the conduit, and internal liabilities (and external claims, if the money is lent to customers) at the level of the subsidiary. Internal debt is not double counted, but total debt is: The same financial flow shows up as (external) debt for the conduit, and as (internal) debt at the subsidiary. Both are part of total debt in unconsolidated data.

\subsection{Bilateral regressions}

Starting from June 2014, the External Positions of Banks database of the Deutsche Bundesbank (2015) also splits up internal liabilities and internal loans by the country of the related affiliate from which the loan is taken or to which the loan is given. This allows to regress bilateral internal net debt on precise bilateral tax rate differentials that unambiguously identify the tax incentive to shift profits between two affiliates. For a subset of German non-financial multinationals, Overesch and Wamser (2014) show a positive effect of such precise tax rate differentials on bilateral debt stocks. So far no study has used bilateral data for estimating debt shifting in banks. Here we use internal liabilities net of internal claims that affiliate $i$ takes out from related affiliates in country $j$ as our dependent variable:

$$
\text { IntNetDebt }_{i j k t}=\max \left(\text { InternalLiabilities }_{i j k t}-\text { InternalClaims }_{i j k t} ; 0\right),
$$

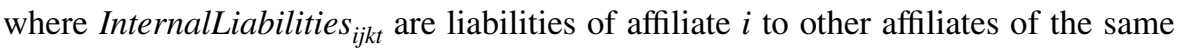
bank group $k$ in country $j$ and InternalClaims ${ }_{i j k t}$ are claims of affiliate $i$ to related affiliates in country $j$. We then estimate the following equation for the full sample of German multinational banks and their foreign affiliates:

$$
\frac{\text { IntNetDebt }_{i j k t}}{T A_{i k t}}=\beta_{0}+\beta_{1}\left(C T R_{i k t}-C T R_{j k t}\right)+\beta_{2} X_{i k t}+\beta_{3} Y_{j k t}+\gamma_{t}+\delta_{k}+u_{i j k t} .
$$

The main variable of interest is $C T R_{i k t}-C T R_{j k t}$ which denotes the bilateral tax rate differential between the host country of affiliate $i$ and the country of the internal 
creditor $j . X_{i k t}$ is the same vector of control variables as above. $Y_{j k t}$ contains the macroeconomic control variables also for the internal net creditor's country. $\gamma_{t}$ are monthly time fixed effects and $\delta_{k}$ are bank group fixed effects. $u_{i j k t}$ is the error term. Under the hypothesis that banks shift profits from higher-taxed to lower-taxed affiliates via internal debt we expect a positive estimate for $\beta_{1}$. Also in this bilateral setting we include bank affiliate fixed effects as a robustness check.

\section{Data and descriptives}

\subsection{Data}

We use the External Position of Banks database of the Deutsche Bundesbank (2015), a unique dataset provided by the German central bank on assets and liabilities in foreign affiliates of German multinational banks and in the respective German headquarters. As this is an administrative dataset to which all German banks with foreign activities are obliged to report monthly, it provides a complete and high quality sample of all German multinational banks. We observe separate records for all subsidiaries, whereas for branches we observe an aggregate figure per bank group and country.

As dependent variables we use internal liabilities held in an affiliate, and internal net debt which is calculated from internal liabilities and internal claims data. For the estimation of Eqs. (1) and (8), these variables are available from June 2010 to December 2015 on a monthly basis. More precise data on bilateral internal loans and liabilities, separated by the country of the internal counterpart, are available from July 2014 until December 2015. Although the sample period for this bilateral data is relatively short, the variation over affiliate/counterparty-country-pairs and over time allows the estimation of Eq. (10) and an identification of the effect of precise corporate tax rate differentials on bilateral internal net debt.

The literature on internal debt shifting usually scales internal debt by total assets. As data on total assets is not available, we proxy total assets by total external assets, which comprise claims against non-residents as well as money market papers, bonds, and shares issued by non-residents. ${ }^{17}$ To control for an affiliate's size, we take the natural logarithm of total external assets as a bank-level control variable. We collect the statutory corporate tax rates on a monthly basis from the Worldwide Corporate Tax Guides of Ernst \& Young $(2011,2014)$. We take country-level controls from the International Monetary Fund's (IMF) International Financial Statistics, the World Development Indicators of the World Bank, the United Nations Conference on Trade and Development (UNCTAD) statistics and the online data centre of the Organisation for Economic Co-operation and Development (OECD). For some countries we have to complement the data with information provided by national statistical offices (see Appendix "Variable definitions" section for an overview of variables and data sources). As nominal

\footnotetext{
17 Claims against the German headquarter are included in the external claims. We discuss below the implications of using external assets instead of total assets for the interpretation of the results.
} 
GDP is only available quarterly, we transform it to monthly frequency with the proportional Denton method for flow series as described in Bloem et al. (2001). Also the share of the financial sector in a country's gross value added is only available with quarterly frequency and we transform it to monthly frequency by cubic spline interpolation. To calculate annual GDP growth rates with monthly frequency, we use interpolated GDP values. Minimum capital requirements are taken from the World Bank (2011) survey on bank regulation. Based on several other questions in this survey, Barth et al. (2013) provide an index on the stringency of capital regulation. As the World Bank provided the most recent version of the survey only in 2011, in our sample these two variables are constant over time. Table 1 shows the basic descriptive statistics of all variables.

\subsection{Descriptive analysis}

Figure 2 illustrates the geographical distribution of German bank affiliates. ${ }^{18}$ Most affiliates are located in Europe, probably due to the proximity to the home country and the common regulation in the European banking union that facilitates foreign activities. The most important foreign market for German banks is Luxembourg with 42 affiliates, followed by the United Kingdom with 32 affiliates (in 2013). Outside Europe the United States (20 affiliates) and Singapore (19 affiliates) are the most important markets.

Furthermore, Fig. 2 illustrates the location of the top 5 countries for conduit debt, defined as the sum of each bank affiliate's min(InternalClaims it $_{i t}$ InternalLiabilities $_{i t}$ ) per country. First note that these most important conduit countries are distributed around the world, suggesting that they serve as regional hubs for different world regions in which German banks are active. Second, three of the five most important conduit countries (Cayman Islands, Luxembourg, Singapore) are classified as tax havens by both Dharmapala and Hines (2009) and Johannesen and Zucman (2014), and also the United Kingdom (the most important conduit country) offers a relatively low tax rate. This observation already suggests that in the sample of German multinational banks conduit entities tend to be located in low-tax countries. The high amount of conduit debt in the United States probably reflects the important role of this financial market. Note that also conduit entities in the United States may face lower effective tax rates than the average U.S. tax rate, as banks can locate their foreign affiliates in Delaware, a well known domestic tax haven in the United States (Dyreng et al. 2013). ${ }^{19}$

\footnotetext{
18 Note that in the External Positions of Banks database of the Deutsche Bundesbank (2015) we observe all subsidiaries of German banks separately. However, we cannot distinguish between different branches of German banks in a country as there is only one aggregate observation per bank group, country and month for branches. We therefore count all branches of a bank group in a country as one single affiliate, whereas all subsidiaries are counted separately.

${ }^{19}$ We do not observe the precise locations of bank affiliates in a country. Therefore, this study assigns to each affiliate in the United States the relatively high average US corporate tax rate, although affiliates might be located in states with low state-level taxes. If German banks systematically locate their affiliates in low-tax states, our results underestimate internal debt shifting.
} 
For a further descriptive investigation of the use of internal debt, Table 2 ranks countries according to the mean of the internal debt-to-assets ratios of German bank affiliates in the respective country in 2013. As expected there are several high-tax countries at the top. German bank affiliates in Japan (corporate tax rate of $38.0 \%$ in 2013) had the highest internal debt-to-asset ratios ( $88.6 \%$ on average). Also the internal debt-to-assets ratio of German bank affiliates in France and Spain (two further high-tax countries) are on a relatively high level around $80 \%$. Also some tax havens appear in the ranking: German bank affiliates in Hong Kong have a similar internal debt ratio as in Portugal, despite the substantially lower corporate tax rate that would suggest that banks shift profits into affiliates in Hong Kong rather than out of them. The last column in Table 2 explains this finding: It reports for each country the average conduit share in internal debt that is passed through an affiliate (formally defined as the country average of $\min \left[\frac{\text { InternalClaims }_{\text {it }}}{\text { InternalLiabilities }_{i t}} ; 1\right]$ in each affiliate). In Hong Kong on average $94.9 \%$ of internal liabilities are merely passed through the affiliates, whereas in Portugal the average conduit share is only $25.7 \%$. Hence, even though German banks have similar internal debt ratios in both countries, the tax-effective internal debt ratio is substantially higher in Portugal. Also bank affiliates in Singapore and the Cayman Islands have similar internal debt ratios as affiliates in high-tax countries (e.g. Italy), which can be explained with substantially larger conduit shares of internal debt.

Both Fig. 2 and Table 2 suggest that the conduit affiliates in the sample of German multinational banks tend to be located in tax havens and low-tax countries, implying an underestimation of debt shifting with the classical dependent variable (the internal-liabilities-to-total-assets ratio). Regressing the conduit share of internal debt in an affiliate on the corporate tax rate and controlling for other macroeconomic variables (see regression results in Appendix "Conduit share regressions") indeed leads to a significantly negative tax coefficient. Hence, in the sample used in this paper, the conduit entities are systematically located in low-tax countries. From a debt shifting perspective this assigns too high internal liabilities to low-taxed affiliates, leading to an underestimation of internal debt shifting with the classical internal-liabilities-to-total-assets ratio as the dependent variable. We therefore expect a larger tax coefficient with the internal-net-debtto-total-assets ratio as the dependent variable.

We now turn to some descriptives for our newly constructed dependent variable, internal net debt. Figure 3 depicts the development of internal net debt in our data over time. The share of internal net debt to total assets is relatively stable over the observation period and amounts to approximately $20 \%$. Bilateral streams of internal net debt are largest between German headquarters and their subsidiaries/branches in Germany, France, the Cayman Islands, the Netherlands, and Spain (see Table 3). Therefore, internal net debt is especially relevant both in countries with many affiliates (see also Table 2) and in an important tax haven country. 
Table 1 Descriptive statistics

\begin{tabular}{llllllll}
\hline Variable & Obs. & Mean & SD & p5 & p50 & p95 & Frequ. \\
\hline Aggregate data (06/2010-12/2015) & & & & & & & \\
Internal liabilities/total assets & 21,896 & 0.424 & 0.414 & 0.000 & 0.285 & 1.000 & $\mathrm{M}$ \\
Internal net debt/total assets & 21,896 & 0.280 & 0.381 & 0.000 & 0.005 & 1.000 & $\mathrm{M}$ \\
Total assets (in million $€$ ) & 21,896 & 8093 & 32,269 & 1 & 1 & 32,878 & $\mathrm{M}$ \\
Statutory corporate tax rate & 21,896 & 0.264 & 0.073 & 0.165 & 0.292 & 0.369 & $\mathrm{M}$ \\
Nominal GDP (in billion $€$ ) & 21,896 & 151 & 210 & 3 & 92 & 370 & $\mathrm{Q} \rightarrow \mathrm{M}$ \\
Inflation rate (\%) & 21,896 & 1.912 & 2.472 & -0.399 & 1.654 & 5.102 & $\mathrm{M}$ \\
GDP growth (\%) & 21,896 & 2.102 & 2.699 & -1.382 & 1.756 & 6.264 & $\mathrm{Q} \rightarrow \mathrm{M}$ \\
Financial sector share & 21,896 & 0.090 & 0.086 & 0.039 & 0.053 & 0.280 & $\mathrm{Q} \rightarrow \mathrm{M}$ \\
Capital requirement & 21,896 & 0.082 & 0.007 & 0.080 & 0.080 & 0.100 & - \\
Regulatory index & 21,896 & 6.956 & 1.734 & 3.000 & 8.000 & 9.000 & - \\
Bilateral data (07/2014-12/2015) & & & & & & & \\
Bilateral internal net debt/total assets & 107,361 & 0.019 & 0.117 & 0.000 & 0.000 & 0.004 & $\mathrm{M}$ \\
Corporate tax rate differential & 107,361 & 0.022 & 0.100 & -0.150 & 0.021 & 0.174 & $\mathrm{M}$ \\
\hline
\end{tabular}

Total assets refer to total external assets including claims against non-residents as well as money market papers, bonds, and shares issued by non-residents. Internal net debt are internal liabilities net of internal loans if positive and zero otherwise. $M$ and $Q$ indicate monthly and quarterly frequency, respectively. Quarterly nominal GDP is transformed to monthly frequency with the proportional Denton method for flow data. Monthly GDP growth is calculated from interpolated GDP values. Financial sector share denotes the share of the finance and insurance sector in a country's gross value added. Monthly frequency is calculated by cubic spline interpolation. Regulatory index is an index for the stringency of capital regulation in a country, ranging from 0 to 10 (higher values indicating greater stringency). Sources: See Appendix "Variable definitions"

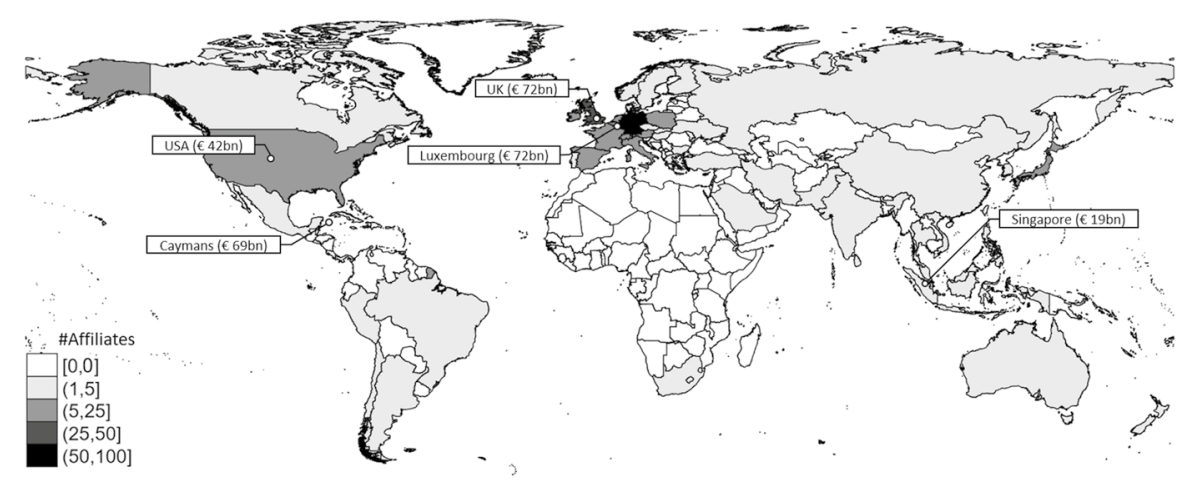

Fig. 2 Number of affiliates shown by different shades; top 5 conduit countries marked in the map, with the sum of conduit debt held by German bank affiliates in the respective country in parentheses (defined as $\min \left(\right.$ InternalClaims $_{i t}$; InternalLiabilities $_{i t}$ ) per affiliate). Own calculations from data of the External Positions of Banks database of Deutsche Bundesbank (2015)

\section{Results}

Table 4 shows the baseline estimation results for the determinants of the internal debt variables in affiliates and headquarters of German multinational banks. For 
Table 2 Intragroup liabilities in 2013

\begin{tabular}{lcll}
\hline Country & CTR $(\%)$ & $\begin{array}{l}\text { Internal Liabilities/ } \\
\text { TA }(\%)\end{array}$ & $\begin{array}{l}\text { Conduit } \\
\text { share }(\%)\end{array}$ \\
\hline Japan & 38.0 & 88.6 & 20.8 \\
France & 34.0 & 83.8 & 22.3 \\
Spain & 30.0 & 79.2 & 7.7 \\
United Kingdom & 23.0 & 75.1 & 43.8 \\
Greece & 26.0 & 74.4 & 38.8 \\
Hong Kong & 16.5 & 72.6 & 94.9 \\
Portugal & 25.0 & 70.9 & 25.7 \\
Sweden & 22.0 & 70.7 & 50.1 \\
Belgium & 34.0 & 69.6 & 32.1 \\
Singapore & 17.0 & 67.0 & 59.0 \\
Italy & 40.7 & 65.2 & 13.1 \\
Cayman Islands & 0.0 & 63.2 & 68.3 \\
United States & 39.1 & 61.1 & 36.8 \\
China & 25.0 & 57.2 & 16.1 \\
.. & & & \\
\hline
\end{tabular}

CTR denotes a country's statutory corporate income tax rate in 2013. Column 3 reports the average gross internal liabilities-to-total external assets ratio of German bank affiliates in the respective country. Column 4 contains the average conduit share of internal debt, defined as the country average of $\min \left(\frac{\text { InternalClaims }_{i t}}{\text { InternalLiabilities }_{i t}} ; 1\right)$ in each affiliate. Due to confidentiality requirements, only countries with at least 3 affiliates are listed. Source: Ernst \& Young $(2011,2014)$ and External Positions of Banks database of Deutsche Bundesbank (2015), own calculations

0.25

0.2

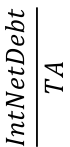

0.15

0.1

0.05

0 2010 2011 2012 2013 2014 2015

Fig. 3 Average of internal net debt over time. For comparison, the average of internal liabilities divided by total assets in 2010 is 0.37. Source: Deutsche Bundesbank (2015), own calculations 
Table 3 Internal net debt: largest bilateral streams

\begin{tabular}{ll}
\hline Country & Internal net debt (\%) \\
\hline Germany & 40.90 \\
France & 26.52 \\
Cayman Islands & 25.90 \\
Netherlands & 25.69 \\
Spain & 25.21
\end{tabular}

Average internal net debt-to-external assets ratio between German bank affiliates in the listed countries and their German headquarter for the five countries with the largest values. Source: Deutsche Bundesbank (2015), own calculations

comparability with previous studies, the dependent variable in column (1) is the ratio of internal liabilities to total (external) assets. We find a significant positive coefficient of 0.508 for the corporate tax rate, indicating that a 10 percentage points higher corporate tax rate implies an increase in the internal liabilities to total assets ratio by about five percentage points. At the mean (42.4\%) this corresponds to an increase by $12 \%$. This effect of corporate tax rates on internal liabilities in the banking sector is quantitatively larger than previous studies estimated for other sectors relative to the sample mean: Fuest et al. (2011) and Buettner et al. (2012) use a similar setting with data on German multinationals and find coefficients for the corporate tax rate of only 0.177 and 0.214 , respectively. A 10 percentage points tax rate increase in these studies implies at the sample means (23\% and 28\%) an increase in the internal debt ratio by around $7 \%$ to $8 \%$. One caveat in the comparison of our results to previous studies is that we have to approximate total assets by total external assets. As we compare changes at the mean, this approximation is innocuous if the ratio of total external assets to total assets remains constant over time.

We can also compare our results to the literature on the effect of taxes on banks' capital structure. This literature finds marginal effects of the tax rate on the total debt-to-assets ratio between 0.25 and 0.3 (Gu et al. 2015; de Mooij and Keen 2016). In further analyses, de Mooij and Keen (2016) show that the tax effect is twice as large after 2007; Heckemeyer and de Mooij (2017) find that small banks react much more strongly than larger banks. ${ }^{20}$ Whereas estimates on the total debt ratio and on internal debt are not directly comparable, a comparison with these results also suggests that banks' internal debt reacts particularly strongly to taxation. ${ }^{21}$

\footnotetext{
${ }^{20}$ This observed heterogeneity among banks may also partially explain why we find a relatively strong response, as our dataset covers both a later period as these other studies, and also more small banks (in contrast to the commercially available datasets used in the papers cited above, our dataset provides full coverage of all German banks with foreign affiliates, no matter how small).

${ }^{21}$ We also estimated the regressions using the ratio of third-party debt to total assets as the dependent variable. However, the results are very imprecisely estimated. For example, in our main specification (col. (7) of Table 4), the 95\%-confidence interval is [- 0.009; 6.330]. Therefore, we cannot compare this result to other studies investigating the effect of taxes on total leverage. This may be due to the fact that we are unable to include further bank-level control variables in our estimations, which are much more relevant for third-party debt than for internal debt (see Sect. 3.1).
} 
Table 4 Baseline intragroup debt regressions

\begin{tabular}{|c|c|c|c|c|c|c|c|c|}
\hline \multirow{3}{*}{$\begin{array}{l}\text { Sample } \\
\text { Dep. var. }\end{array}$} & \multicolumn{4}{|l|}{ All entities } & \multicolumn{4}{|c|}{ Foreign affiliates } \\
\hline & \multirow{2}{*}{$\begin{array}{l}\frac{\text { IntLiab }}{T A} \\
(1)\end{array}$} & \multicolumn{3}{|l|}{$\frac{\text { IntNetDebt }}{T A}$} & \multirow{2}{*}{$\begin{array}{l}\frac{\text { IntLiab }}{T A} \\
(5)\end{array}$} & \multicolumn{3}{|l|}{$\frac{\text { IntNetDebt }}{T A}$} \\
\hline & & (2) & (3) & (4) & & (6) & (7) & (8) \\
\hline CTR & $\begin{array}{l}0.508^{*} \\
(0.270)\end{array}$ & $\begin{array}{l}0.565 * * \\
(0.225)\end{array}$ & $\begin{array}{l}0.363 * * \\
(0.146)\end{array}$ & & $\begin{array}{l}0.468 * \\
(0.265)\end{array}$ & $\begin{array}{l}0.511 * * \\
(0.214)\end{array}$ & $\begin{array}{l}0.344 * * \\
(0.151)\end{array}$ & \\
\hline GroupCTR & & & & $\begin{array}{l}-0.540^{* *} \\
(0.219)\end{array}$ & & & & $\begin{array}{l}-1.036^{* * *} \\
(0.252)\end{array}$ \\
\hline $\operatorname{Ln}(\mathrm{TA})$ & $\begin{array}{l}-0.024^{* * *} \\
(0.007)\end{array}$ & $\begin{array}{l}-0.015^{* * *} \\
(0.006)\end{array}$ & $\begin{array}{l}0.009 * * \\
(0.003)\end{array}$ & $\begin{array}{l}0.006^{*} \\
(0.003)\end{array}$ & $\begin{array}{l}-0.004 \\
(0.007)\end{array}$ & $\begin{array}{l}0.006 \\
(0.006)\end{array}$ & $\begin{array}{l}0.016 * * * \\
(0.004)\end{array}$ & $\begin{array}{l}0.013 * * * \\
(0.004)\end{array}$ \\
\hline $\operatorname{Ln}(G D P)$ & $\begin{array}{l}0.019 \\
(0.015)\end{array}$ & $\begin{array}{l}-0.000 \\
(0.012)\end{array}$ & $\begin{array}{l}0.010 \\
(0.023)\end{array}$ & $\begin{array}{l}-0.006 \\
(0.023)\end{array}$ & $\begin{array}{l}0.022 \\
(0.014)\end{array}$ & $\begin{array}{l}0.000 \\
(0.011)\end{array}$ & $\begin{array}{l}0.020 \\
(0.024)\end{array}$ & $\begin{array}{l}0.007 \\
(0.024)\end{array}$ \\
\hline Inflation & $\begin{array}{l}-0.007 * \\
(0.004)\end{array}$ & $\begin{array}{l}-0.005^{* *} \\
(0.003)\end{array}$ & $\begin{array}{l}-0.000 \\
(0.001)\end{array}$ & $\begin{array}{l}-0.000 \\
(0.001)\end{array}$ & $\begin{array}{l}-0.013^{* * *} \\
(0.004)\end{array}$ & $\begin{array}{l}-0.008^{* * *} \\
(0.003)\end{array}$ & $\begin{array}{l}0.000 \\
(0.000)\end{array}$ & $\begin{array}{l}-0.000 \\
(0.001)\end{array}$ \\
\hline $\begin{array}{l}\text { GDP } \\
\text { growth }\end{array}$ & $\begin{array}{l}-0.010^{* *} \\
(0.004)\end{array}$ & $\begin{array}{l}-0.008^{* *} \\
(0.004)\end{array}$ & $\begin{array}{l}-0.001 \\
(0.001)\end{array}$ & $\begin{array}{l}-0.001^{*} \\
(0.001)\end{array}$ & $\begin{array}{l}-0.011^{* * *} \\
(0.004)\end{array}$ & $\begin{array}{l}-0.009^{* * *} \\
(0.003)\end{array}$ & $\begin{array}{l}-0.001 \\
(0.001)\end{array}$ & $\begin{array}{l}-0.001 \\
(0.001)\end{array}$ \\
\hline $\begin{array}{l}\text { Fin. sector } \\
\text { share }\end{array}$ & $\begin{array}{l}0.879 * * * \\
(0.318)\end{array}$ & $\begin{array}{l}0.102 \\
(0.230)\end{array}$ & $\begin{array}{l}1.409 * * * \\
(0.225)\end{array}$ & $\begin{array}{l}1.552 * * * \\
(0.239)\end{array}$ & $\begin{array}{l}0.495 \\
(0.310)\end{array}$ & $\begin{array}{l}-0.285 \\
(0.219)\end{array}$ & $\begin{array}{l}1.543 * * * \\
(0.227)\end{array}$ & $\begin{array}{l}1.744 * * * \\
(0.242)\end{array}$ \\
\hline Reg. index & $\begin{array}{l}-0.018^{* *} \\
(0.009)\end{array}$ & $\begin{array}{l}-0.005 \\
(0.008)\end{array}$ & & & $\begin{array}{l}0.003 \\
(0.008)\end{array}$ & $\begin{array}{l}0.018 * * * \\
(0.007)\end{array}$ & & \\
\hline Cap. req. & $\begin{array}{l}0.221 \\
(2.735)\end{array}$ & $\begin{array}{l}1.256 \\
(1.975)\end{array}$ & & & $\begin{array}{l}-0.544 \\
(2.451)\end{array}$ & $\begin{array}{l}-0.544 \\
(1.775)\end{array}$ & & \\
\hline Time FE & $\checkmark$ & $\checkmark$ & $\checkmark$ & $\checkmark$ & $\checkmark$ & $\checkmark$ & $\checkmark$ & $\checkmark$ \\
\hline $\begin{array}{l}\text { Bank } \\
\text { group } \\
\text { FE }\end{array}$ & $\checkmark$ & $\checkmark$ & $\checkmark$ & $\checkmark$ & $\checkmark$ & $\checkmark$ & $\checkmark$ & $\checkmark$ \\
\hline Bank FE & & & $\checkmark$ & $\checkmark$ & & & $\checkmark$ & $\checkmark$ \\
\hline$R^{2}$ & 0.359 & 0.332 & 0.799 & 0.795 & 0.403 & 0.484 & 0.781 & 0.777 \\
\hline $\begin{array}{l}\text { Observa- } \\
\text { tions }\end{array}$ & 21,896 & 21,896 & 21,893 & 21,884 & 16,187 & 16,187 & 16,184 & 16,181 \\
\hline
\end{tabular}

Dependent variable is the ratio of internal liabilities to total external assets in columns (1) and (4) and the ratio of internal net debt (internal liabilities net of internal claims if positive, zero otherwise) to total external assets in the other columns. groupCTR is the average tax rate of the bank group. Fin. sector share is the share of the banking and insurance sector in a country's gross value added. Reg. index captures the stringency of capital regulation in a country, ranging from 0 to 10 (higher values indicating greater stringency). Cap. req. is the legal minimum capital requirement for banks in a country. Standard errors in parentheses, clustered by bank and by country-month. ***,***, indicate significance at the $1 \%$, 5\%, 10\% levels. Regressions based on monthly data for 06/2010-12/2015 from the External Positions of Banks database of Deutsche Bundesbank (2015)

The greater impact of tax rates on internal debt in the financial sector becomes even clearer if we use internal net debt as the dependent variable in column (2). This variable reflects the effective amount of debt that shifts profits out of an affiliate. As shown in the previous section, as conduit entities in internal debt financing are mainly located in low-tax countries, ignoring conduit debt results in a downward biased estimate of the tax coefficient when using internal gross liabilities as proxy for debt shifting. The tax coefficient in column (2) is 0.565 , which is about $11 \%$ 
larger than the estimate in column (1). A Wald test shows that the coefficient estimate in column (2) is significantly larger than the coefficient estimate in column (1) at a significance level of $10 \%$. While the relatively low significance level implies that one should interpret this result cautiously, it does nevertheless suggest that using internal net debt as the dependent variable tends to provide stronger results than using the traditional internal liabilities variable. At the sample mean (28.0\%), a 10 percentage points higher corporate tax rate implies an increase in the internalnet-debt-to-total-assets ratio by $20 \%$. Previous literature has not analysed the tax response of internal net debt, and therefore comparability to non-financial sectors is limited in column (2). However, as also non-banks use conduit entities (e.g. internal financing hubs), accounting for conduit debt is an interesting extension for future research on debt shifting in non-financial sectors.

In column (3) we additionally include bank affiliate fixed effects. Qualitatively we can confirm that multinational banks shift profits through the use of internal debt; however the estimated coefficient is smaller. As fixed effects models assume that the full effect of a tax rate change on internal debt takes place within the same period, the smaller coefficient may indicate that banks respond more slowly. ${ }^{22}$ In addition, the fixed effects specification uses only tax rate changes for identification, and the bulk of these changes took place in high-tax countries. As tax havens (the potential destinations for profits) still offer a much lower tax rate (but did not change their tax rate), the tax incentive for internal debt structures often changes little if only countries with medium or high tax rates make changes. This results in relatively low adjustments to tax rate changes (see also Davies et al. 2018). Still, the estimated coefficient indicates a strong response of internal net debt to corporate tax rates: A ten percentage points rise in the tax rate implies an increase in the internal net debt ratio by 3.63 percentage points, corresponding to an increase by about $13 \%$ at the sample mean.

Instead of the tax rate affiliate $i$ is facing, in column (4) we use the average tax rate in the bank group as our main explanatory variable. Relying on variation in foreign taxation allows us to more carefully disentangle profit shifting from tax debt shielding. The group tax coefficient in column (4) is negative and statistically significant, indicating that an increase in the average group tax rate lowers internal debt. If the average group tax rate increases, shifted profits are on average taxed at a higher rate, reducing the incentive to increase internal lending for profit shifting.

Columns (5) to (8) show the results of re-estimating the four specifications with exclusion of German headquarters. This accounts for the idiosyncrasy of the External Positions of Banks database that all headquarters reside in Germany, and Dischinger et al. (2014) show that multinationals might be reluctant to shift profits away from headquarters. However, we find smaller tax coefficients $(0.468,0.511$

\footnotetext{
22 Additionally, the noise-to-effect ratio is higher in the fixed effects model, so that measurement error in the variables (which may arise e.g. due to book-tax differences) leads to more attenuation bias.
} 
Table 5 Bilateral regression results

\begin{tabular}{|c|c|c|c|c|}
\hline \multirow{3}{*}{$\begin{array}{l}\text { Sample } \\
\text { Dep. var. }\end{array}$} & \multicolumn{2}{|l|}{ All entities } & \multicolumn{2}{|c|}{ Foreign affiliates } \\
\hline & \multicolumn{4}{|l|}{$\frac{\text { IntNetDebt }_{i j t}}{T A_{i}}$} \\
\hline & (1) & (2) & (3) & (4) \\
\hline \multirow[t]{2}{*}{$C T R_{i t}-C T R_{j t}$} & $0.033 * * *$ & $0.042 * * *$ & $0.059 * * *$ & $0.094 * * *$ \\
\hline & $(0.007)$ & $(0.008)$ & $(0.008)$ & $(0.010)$ \\
\hline \multirow[t]{2}{*}{ Ln(Total assets) } & $-0.009 * * *$ & $-0.008 * * *$ & $-0.005^{* * *}$ & $-0.008 * * *$ \\
\hline & $(0.000)$ & $(0.002)$ & $(0.001)$ & $(0.003)$ \\
\hline \multicolumn{5}{|l|}{$\operatorname{Ln}(G D P)$} \\
\hline \multirow[t]{2}{*}{ Host country $i$} & $0.002 * * *$ & 0.005 & 0.001 & 0.005 \\
\hline & $(0.001)$ & $(0.005)$ & $(0.001)$ & $(0.007)$ \\
\hline \multirow[t]{2}{*}{ Counterpart $j$} & $0.008 * * *$ & $0.006 * * *$ & $0.012 * * *$ & $0.013 * * *$ \\
\hline & $(0.001)$ & $(0.001)$ & $(0.001)$ & $(0.001)$ \\
\hline \multicolumn{5}{|l|}{ Inflation rate } \\
\hline \multirow[t]{2}{*}{ Host country $i$} & $-0.002 * * *$ & $-0.001 * *$ & $-0.002 * * *$ & -0.000 \\
\hline & $(0.000)$ & $(0.000)$ & $(0.000)$ & $(0.000)$ \\
\hline \multirow[t]{2}{*}{ Counterpart $j$} & $-0.001 * * *$ & $-0.001 * * *$ & $-0.001 * * *$ & $-0.001 * * *$ \\
\hline & $(0.000)$ & $(0.000)$ & $(0.000)$ & $(0.000)$ \\
\hline \multicolumn{5}{|l|}{ GDP growth } \\
\hline \multirow[t]{2}{*}{ Host country $i$} & $-0.001 * * *$ & $-0.000 * *$ & $-0.001 * * *$ & -0.000 \\
\hline & $(0.000)$ & $(0.000)$ & $(0.000)$ & $(0.000)$ \\
\hline \multirow[t]{2}{*}{ Counterpart $j$} & $-0.001 * * *$ & $-0.001 * * *$ & $-0.002 * * *$ & $-0.002 * * *$ \\
\hline & $(0.000)$ & $(0.000)$ & $(0.000)$ & $(0.000)$ \\
\hline \multicolumn{5}{|l|}{ Regulatory index } \\
\hline \multirow[t]{2}{*}{ Host country $i$} & -0.000 & & $0.001 * * *$ & \\
\hline & $(0.000)$ & & $(0.000)$ & \\
\hline \multirow[t]{2}{*}{ Counterpart $j$} & $0.004 * * *$ & $0.003 * * *$ & $0.007 * * *$ & $0.006^{* * * *}$ \\
\hline & $(0.001)$ & $(0.001)$ & $(0.000)$ & $(0.000)$ \\
\hline \multicolumn{5}{|c|}{ Capital requirement } \\
\hline \multirow[t]{2}{*}{ Host country $i$} & $0.453 * * *$ & & $0.397 * * *$ & \\
\hline & $(0.079)$ & & $(0.072)$ & \\
\hline \multirow[t]{2}{*}{ Counterpart $j$} & $-0.344 * * *$ & $-0.281 * * *$ & $-0.375^{* * *}$ & $-0.365^{* * *}$ \\
\hline & $(0.026)$ & $(0.023)$ & $(0.036)$ & $(0.035)$ \\
\hline \multicolumn{5}{|c|}{ Financial sector share } \\
\hline \multirow[t]{2}{*}{ Host country $i$} & $0.077 * * *$ & $-0.143 * * *$ & $0.067 * * *$ & $-0.161 * *$ \\
\hline & $(0.012)$ & $(0.053)$ & $(0.012)$ & $(0.063)$ \\
\hline \multirow[t]{2}{*}{ Counterpart $j$} & $0.031 * * *$ & $0.026 * * *$ & $0.045^{* * *}$ & $0.038 * * *$ \\
\hline & $(0.004)$ & $(0.003)$ & $(0.008)$ & $(0.006)$ \\
\hline Monthly time FE & $\checkmark$ & $\checkmark$ & $\checkmark$ & $\checkmark$ \\
\hline Bank group FE & $\checkmark$ & $\checkmark$ & $\checkmark$ & $\checkmark$ \\
\hline Bank FE & & $\checkmark$ & & $\checkmark$ \\
\hline$R^{2}$ & 0.078 & 0.231 & 0.146 & 0.241 \\
\hline Observations & 107,361 & 107,361 & 57,628 & 57,628 \\
\hline
\end{tabular}


Table 5 (continued)

$i$ indicates the affiliate and $j$ the country of the internal counterpart to/from which loans are given/ obtained. $\frac{\text { IntNetDebt }_{i j}}{T A_{i}}$ is the ratio of internal liabilities net of internal claims between affiliate $i$ and affiliates of the same bank group in country $j$ relative to total external assets of affiliate $i$ if positive, and zero otherwise. Regulatory index captures the stringency of capital regulation in a country, ranging from 0 to 10 (higher values indicating greater stringency). Standard errors in parentheses, clustered by bank-counterpart-pairs and country-month. ***, **, * indicate significance at the $1 \%, 5 \%, 10 \%$ levels. Monthly bilateral bank data for 07/2014-12/2015 from the External Positions of Banks database of Deutsche Bundesbank (2015)

and 0.344) when excluding headquarters from our sample of German multinational banks. There are several potential explanations for this finding: First, banks might use debt shifting to substantially shift profits out of their German headquarters. This would be in line with Tørsløv et al. (2020) who show that the share of corporate tax revenues lost due to profit shifting in Germany is the highest among all European countries. Second, headquarters partially finance their foreign affiliates with internal debt, leading to a 'base' stock of internal debt in these affiliates that does not respond to tax rates and leads to the smaller estimated responses in regressions (5) to (7).

Results on control variables furthermore show a small negative effect of an affiliate's size (measured in total external assets) on the use of internal debt in the full sample without affiliate fixed effects, but estimates in the subsample of foreign affiliates are insignificant. When including affiliate dummies, the effect gets slightly positive. Inflation rates in the host country have a significantly negative impact on both the internal-gross-liabilities-to-total-assets ratio and the internal-net-debt ratio, perhaps reflecting higher risks. When including affiliate fixed effects, this effect vanishes. A negative effect also arises from GDP growth, possibly because banks do not shift funds away from affiliates in fast growing countries. As expected, the share of the financial sector in a country's gross value added has a significantly positive effect on the internal-gross-liabilities-to-total-assets ratio in regression (1). However, on the internal-net-debt ratio we can only find a positive effect when including bank affiliate fixed effects.

Table 5 shows results of the bilateral debt shifting regressions that allow use of the precise corporate tax rate differential as a measure for the shifting incentive. For this tax rate differential a significantly positive effect on bilateral-internal-net-debtto-total-assets of 0.033 arises in the baseline regression, and of 0.042 when including affiliate fixed effects. In the subsample of foreign affiliates these effects are even 
larger: In regression (3) a coefficient of 0.059 arises, meaning that a 10 percentage points higher corporate tax rate differential leads to an increase in the bilateral-internal-net-debt ratio by 0.59 percentage points. Compared to the sample mean $(3.2 \%$ in foreign affiliates) this corresponds to an increase of $18 \%$. This result is in line with banks shifting profits through internal debt from higher-taxed to lower-taxed affiliates. Moreover, this implied semi-elasticity also quantitatively confirms the $20 \%$ increase in internal net debt ratio (in response to a 10 percentage points corporate tax rate increase) which we find in Table 4. When controlling for affiliate fixed effects in column (4), the estimated coefficient increases even further to 0.094.

Note that in the bilateral debt regressions in Table 5 the estimated tax effect increases when including bank affiliate dummies, whereas with aggregate internal net debt as the dependent variable in Table 4 the tax effect is smaller with bank affiliate dummies. This implies that internal net debt is highly responsive to changes in the internal counterpart's tax rate (the potential destination for profits), whereas banks do not respond equally strongly to changes in the host country's tax rate.

Results on host country control variables of affiliate $i$ are qualitatively similar to the estimates for aggregate debt data in Table 4. In bilateral regressions we also include macroeconomic control variables for the country from which the internal net debt is taken. For the internal counterpart's country we find a positive effect of the GDP that probably comes from the fact that German banks partially finance a stronger engagement in large countries through internal debt. Interestingly, the capital requirement in the internal counterpart's country has a significantly negative effect on bilateral internal net debt: Additional claims have to be backed by additional equity to fulfil capital requirements; hence a higher capital requirement can discourage internal lending.

To summarize, both aggregate and bilateral internal debt regressions on German multinational banks indicate that banks engage in debt shifting. Moreover, the estimated effect in the banking sector is larger than previous studies estimated for non-financial firms, both absolutely and relative to the sample average of internal debt ratios. This becomes even clearer when we correct for conduit entities: Since conduit affiliates are taxed lower than the sample average, using the internal-netdebt ratio as the dependent variable leads to even larger estimated tax responses. 
Accounting for conduit debt is also a more general methodological issue that can be addressed by future empirical internal debt shifting studies on non-banks.

\section{Conclusion}

The immaterial nature of the banking business and the concentrated expertise in the optimal design of financial transactions suggest that the financial sector may use its tax planning possibilities more aggressively than other sectors do. However, there are only a few studies considering tax avoidance in the banking sector. Contributing to this literature, our paper is the first that investigates internal debt shifting in the financial sector. We show that banks engage in debt shifting, with a ten percentage points higher tax rate increasing the internal-net-debt-to-total-assets ratio by about 5.7 percentage points. At the mean this corresponds to an increase of $20 \%$. Moreover, a comparison of our results to previous studies on non-financial firms suggests that banks use debt shifting more aggressively.

We furthermore show that it is important to account for conduit entities in internal debt financing, as results with the classical measure for internal debt shifting are downward biased. This mismeasurement is not only important in the context of internal debt shifting in the financial sector, but also for multinationals in general. Anecdotal evidence shows that also multinational enterprises in other sectors establish affiliates acting as internal banks (The Guardian 2014). If these internal banks are mainly located in low-tax countries, previous studies have underestimated the extent of tax avoidance through the use of internal debt. Similarly, studies measuring tax impacts on capital structure more generally may also suffer from measurement error and should use net positions.

Acknowledgements We thank Ulrich Glogowsky, Andreas Haufler, Marko Köthenbürger, Dirk Schindler and participants of the annual conference of the German Economic Association, the Public Economics Research Seminar at the ifo Institute and at the University of Munich for helpful comments and suggestions. Reiter gratefully acknowledges financial support from the Egon-Sohmen-Foundation. We also thank the Deutsche Bundesbank for granting access to the External Positions of Banks database. A previous version of the paper was circulated under the authorship of Reiter; Langenmayr and Holtmann joined the project later.

Funding Open Access funding provided by Projekt DEAL.. Open Access funding provided by Projekt DEAL. 
Open Access This article is licensed under a Creative Commons Attribution 4.0 International License, which permits use, sharing, adaptation, distribution and reproduction in any medium or format, as long as you give appropriate credit to the original author(s) and the source, provide a link to the Creative Commons licence, and indicate if changes were made. The images or other third party material in this article are included in the article's Creative Commons licence, unless indicated otherwise in a credit line to the material. If material is not included in the article's Creative Commons licence and your intended use is not permitted by statutory regulation or exceeds the permitted use, you will need to obtain permission directly from the copyright holder. To view a copy of this licence, visit http://creativecommons.org/licen ses/by/4.0/.

\section{Appendix}

\section{Variable definitions}

See Table 6.

Table 6 Variable definitions and sources

\begin{tabular}{|c|c|}
\hline Variable & Definition \\
\hline \multicolumn{2}{|c|}{ Bank-level variables from Deutsche Bundesbank (2015) } \\
\hline Internal liabilities (IntLiab) & Liabilities to affiliates of the same bank group \\
\hline Internal claims & Claims to affiliates of the same bank group \\
\hline Internal net debt (IntNetDebt) & $\begin{array}{l}\text { Volume of internal liabilities that effectively shift profits out of an affili- } \\
\text { ate, defined as } \max (\text { IntLiab - InternalClaims;0) }\end{array}$ \\
\hline Total assets $(T A)$ & Total external assets of an affiliate \\
\hline Conduit debt & $\begin{array}{l}\text { Internal liabilities that are effectively passed through an affiliate (i.e. } \\
\text { being opposed by internal claims of the same amount); defined as } \\
\text { min(InternalClaims; IntLiab) }\end{array}$ \\
\hline Conduit share & $\begin{array}{l}\text { Share of internal liabilities that are passed through an affiliate, defined as } \\
\min \left(\frac{\text { InternalClaims }}{\text { IntLiab }} ; 1\right)\end{array}$ \\
\hline \multicolumn{2}{|l|}{ Country-level variables } \\
\hline Corporate tax rate (CTR) & $\begin{array}{l}\text { Statutory corporate tax rate on bank profits (Source: Ernst \& Young } \\
\text { 2011, 2014) }\end{array}$ \\
\hline GDP & $\begin{array}{l}\text { Nominal gross domestic product, monthly values interpolated with } \\
\text { the proportional Denton method (Bloem et al. 2001) (Source: IMF, } \\
\text { OECD*) }\end{array}$ \\
\hline Inflation rate & Consumer price inflation rate (Source: $\mathrm{IMF}^{*}$ ) \\
\hline GDP growth & Annual growth rate of real GDP (Source: IMF*) \\
\hline Financial sector share & $\begin{array}{l}\text { Share of the banking and insurance sector in a country's gross value } \\
\text { added, monthly values interpolated using cubic spline interpolation } \\
(\text { Source: OECD*) }\end{array}$ \\
\hline Capital requirement & $\begin{array}{l}\text { Minimum regulatory capital requirement for banks (Source: World Bank } \\
\text { 2011) }\end{array}$ \\
\hline Regulatory index & $\begin{array}{l}\text { Index on capital regulation, capturing whether capital requirements are } \\
\text { adjusted for individual risk of banks, whether the regulatory capital } \\
\text { is adjusted for certain market value losses and whether certain funds } \\
\text { may be used to capitalize a bank; ranging from } 0 \text { (low stringency) to } 10 \\
\text { (high stringency) (Source: Barth et al. 2013) }\end{array}$ \\
\hline
\end{tabular}

Data sources marked with a * are complemented by data from national statistical offices 


\section{Conduit share regressions}

See Table 7.

Table 7 Regressions on affiliates' conduit shares

\begin{tabular}{llll}
\hline Dep. var. & \multicolumn{3}{l}{ Conduit share in internal debt } \\
\cline { 2 - 4 } & $(1)$ & $(2)$ & $(3)$ \\
\hline CTR & $-0.550^{* * *}$ & $-0.527 * * *$ & $-0.347^{* * *}$ \\
& $(0.048)$ & $(0.047)$ & $(0.044)$ \\
Ln(TA) & $-0.005^{* * * *}$ & $0.006^{* * *}$ & -0.001 \\
& $(0.001)$ & $(0.001)$ & $(0.001)$ \\
Ln(Population) & $-0.032^{* * * *}$ & $-0.034^{* * *}$ & $-0.037 * * *$ \\
& $(0.003)$ & $(0.003)$ & $(0.003)$ \\
Inflation rate & $0.018^{* * *}$ & $0.022^{* * *}$ & $0.016^{* * *}$ \\
& $(0.001)$ & $(0.001)$ & $(0.001)$ \\
GDP growth & $0.011^{* * *}$ & $0.015^{* * *}$ & $0.006^{* * *}$ \\
& $(0.001)$ & $(0.001)$ & $(0.001)$ \\
Financial sector share & $0.407 * * *$ & $0.387 * * *$ & $0.361^{* * *}$ \\
& $(0.062)$ & $(0.062)$ & $(0.059)$ \\
Headquarter & $0.379 * * *$ & $0.372^{* * *}$ & $0.468^{* * *}$ \\
Regulatory index & $(0.009)$ & $(0.009)$ & $(0.010)$ \\
Capital requirement & $-0.029^{* * * *}$ & $-0.028^{* * * *}$ & $-0.025^{* * *}$ \\
& $(0.002)$ & $(0.002)$ & $(0.002)$ \\
Monthly time FE & $-3.091^{* * * *}$ & $-3.580^{* * * *}$ & $-5.598^{* * *}$ \\
Bank group FE & $(0.489)$ & $(0.487)$ & $(0.445)$ \\
$R^{2}$ & & $\checkmark$ & $\checkmark$ \\
Observations & & & $\checkmark$ \\
\hline Depent & 0.127 & 0.147 & 0.345 \\
& 19,754 & 19,754 & 19,754 \\
\hline
\end{tabular}

Dependent variable is the share of conduit debt in total internal liabilities as defined by $\max \left(\frac{\text { InternalClaims }_{\text {it }}}{\text { InternalLiabilities }_{i t}} ; 1\right) . \operatorname{Ln}(T A)$ is the natural logarithm of affiliate $i$ 's total external assets. Financial sector share is the share of the banking and insurance sector in a country's gross value added. Headquarter is a dummy indicating whether affiliate $i$ is a German headquarter. Regulatory index captures the stringency of capital regulation in a country, ranging from 0 to 10 (higher values indicating greater stringency). Standard errors in parentheses. $* * * * * *$ indicate significance at the $1 \%, 5 \%, 10 \%$ levels. Monthly bank data for 06/2010-12/2015 from the External Positions of Banks database of Deutsche Bundesbank (2015) 


\section{References}

Bank for International Settlements. (2017). International Banking Statistics. http://stats.bis.org.

Barth, J. R., Caprio, G., \& Levine, R. (2013). Bank regulation and supervision in 180 countries from 1999 to 2011. Journal of Financial Economic Policy, 5, 111-219.

Basel Committee on Banking Supervision. (2006). International convergence of capital measurement and capital standards.

Beer, S., de Mooij, R., \& Liu, L. (2020). International corporate tax avoidance: A review of the channels, magnitudes and blind spots. Journal of Economic Surveys, 34, 660-688.

Berg, T., \& Gider, J. (2017). What explains the difference in leverage between banks and non-banks? Journal of Financial and Quantitative Analysis, 52, 2677-2702.

Bloem, A. M., Dippelsman, R. J., \& Mæhle, N. Ø. (2001). Manual for quarterly national accounts: concepts, data sources, and compilation. Washington DC: International Monetary Fund.

Blouin, J., Huizinga, H., Laeven, L., \& Nicodeme, G. (2014). Thin capitalization rules and multinational firm capital structure. CESifo Working Paper 4695.

Blümich, W., \& Vogt, G. (2019). EStG, KStG, GewStG. AStG $§ 8$ Einkünfte von Zwischengesellschaften.

Buch, C. M., Hilberg, B., \& Tonzer, L. (2016). Taxing banks: An evaluation of the German bank levy. Journal of Banking \& Finance, 72, 52-66.

Buettner, T., Overesch, M., Schreiber, U., \& Wamser, G. (2012). The impact of thin capitalization rules on the capital structure of multinational firms. Journal of Public Economics, 96, 930-938.

Buettner, T., \& Wamser, G. (2013). Internal debt and multinational profit shifting: Empirical evidence from firm-level panel data. National Tax Journal, 66, 63-96.

Cocco, J. F., Gomes, F. J., \& Martins, N. C. (2009). Lending relationships in the interbank market. Journal of Financial Intermediation, 18, 24-48.

Davies, R. B., Martin, J., Parenti, M., \& Toubal, F. (2018). Knocking on tax Haven's door: Multinational firms and transfer pricing. Review of Economics and Statistics, 100, 120-134.

de Mooij, R., \& Keen, M. (2016). Debt, taxes, and banks. Journal of Money, Credit and Banking, 48, 5-33.

Dermine, J. (2015). Basel III leverage ratio requirement and the probability of bank runs. Journal of Banking \& Finance, 53, 266-277.

Desai, M. A., Foley, C. F., \& Hines, J. (2004). A multinational perspective on capital structure choice and internal capital markets. Journal of Finance, 59, 2451-2487.

Deutsche Bundesbank. (2015). External positions of banks database 2010-2015.

Deutsche Bundesbank. (2016). Monthly Report October 2016.

Devereux, M., Johannesen, N., \& Vella, J. (2019). Can taxes tame the banks? Evidence from the European bank levies. The Economic Journal, 129, 3058-3091.

Dharmapala, D. (2014). What do we know about base erosion and profit shifting? A review of the empirical literature. Fiscal Studies, 35, 421-448.

Dharmapala, D., \& Hines, J. R. (2009). Which countries become tax havens? Journal of Public Economics, 93, 1058-1068.

Dischinger, M., Knoll, B., \& Riedel, N. (2014). The role of headquarters in multinational profit shifting strategies. International Tax and Public Finance, 21, 248-271.

Dyreng, S. D., Lindsey, B. P., Markle, K. S., \& Shackelford, D. A. (2015). The effect of tax and nontax country characteristics on the global equity supply chains of U.S. multinationals. Journal of Accounting and Economics, 59, 182-202.

Dyreng, S. D., Lindsey, B. P., \& Thornock, J. R. (2013). Exploring the role Delaware plays as a domestic tax haven. Journal of Financial Economics, 108, 751-772.

Egger, P., Keuschnigg, C., Merlo, V., \& Wamser, G. (2014). Corporate taxes and internal borrowing within multinational firms. American Economic Journal: Economic Policy, 6, 54-93.

Elliott, M., Golub, B., \& Jackson, M. O. (2014). Financial networks and contagion. American Economic Review, 104, 3115-3153.

Ernst \& Young $(2011,2014)$. Worldwide corporate tax guide. http://www.ey.com/GL/en/Services/ Tax/Global-tax-guide-archive.

Feld, L., Heckemeyer, J., \& Overesch, M. (2013). Capital structure choice and company taxation: A meta-study. Journal of Banking \& Finance, 37, 2850-2866. 
Fuest, C., Hebous, S., \& Riedel, N. (2011). International debt shifting and multinational firms in developing economies. Economics Letters, 113, 135-138.

Fuest, C., \& Hemmelgarn, T. (2005). Corporate tax policy, foreign firm ownership, and thin capitalization. Regional Science and Urban Economics, 35, 508-526.

Garcia-Bernardo, J., Fichtner, J., Takes, F. W., \& Heemskerk, E. M. (2017). Uncovering offshore financial centers: Conduits and sinks in the global corporate ownership network. Scientific Reports, 7, 1-10.

Gu, G. W., de Mooij, R., \& Poghosyan, T. (2015). Taxation and leverage in international banking. International Tax and Public Finance, 22, 177-200.

Heckemeyer, J., \& de Mooij, R. (2017). Taxation and corporate debt: Are banks any different? National Tax Journal, 70, 53-76.

Internal Revenue Service. (2019). 2015 Income tax returns complete report. www.irs.gov/statistics/ soi-tax-stats-corporation-complete-report.

Johannesen, N. (2014). Tax avoidance with cross-border hybrid instruments. Journal of Public Economics, 112, 40-52.

Johannesen, N., \& Zucman, G. (2014). The end of bank secrecy? An evaluation of the G20 tax haven crackdown. American Economic Journal: Economic Policy, 6, 65-91.

Langenmayr, D., \& Reiter, F. (2017). Trading offshore: Evidence on banks' tax avoidance. CESifo Working Paper No. 6664.

Merz, J., \& Overesch, M. (2016). Profit shifting and tax response of multinational banks. Journal of Banking and Finance, 68, 57-68.

Mintz, J., \& Smart, M. (2004). Income shifting, investment, and tax competition: Theory and evidence from provincial taxation in Canada. Journal of Public Economics, 88, 1149-1168.

Mintz, J. M. (2004). Conduit entities: Implications of indirect tax-efficient financing structures for real investment. International Tax and Public Finance, 11, 419-434.

Mintz, J. M., \& Weichenrieder, A. J. (2010). The indirect side of direct investment. CESifo book series. Cambridge: MIT Press.

Møen, J., Schindler, D., Schjelderup, G., \& Bakke, J. T. (2019). International debt shifting: The valuemaximizing mix of internal and external debt. International Journal of the Economics of Business, 26, 431-465.

Overesch, M., \& Wamser, G. (2014). Bilateral internal debt financing and tax planning of multinational firms. Review of Quantitative Finance and Accounting, 42, 191-209.

Ruf, M., \& Weichenrieder, A. J. (2012). The taxation of passive foreign investment: Lessons from German experience. Canadian Journal of Economics, 45, 1504-1528.

Statistisches Bundesamt. (2019). Finanzen und Steuern: Körperschaftsteuerstatistik 2014.

The Guardian. (2014). Luxembourg tax files: How Juncker's duchy accommodated Skype and the Koch empire. The Guardian, article by Simon Bowers, 9 December 2014.

Tørsløv, T., Wier, L., \& Zucman, G. (2020). Externalities in international tax enforcement: Theory and evidence. NBER Working Paper 26899.

World Bank. (2011). Survey on bank regulation. http://go.worldbank.org/WFIEF81AP0.

Publisher's Note Springer Nature remains neutral with regard to jurisdictional claims in published maps and institutional affiliations. 